\title{
Notes on the Holocene marine fauna of eastern North Greenland
}

\author{
OLE BENNIKE, SVEND FUNDER AND CHRISTIAN HJORT
}

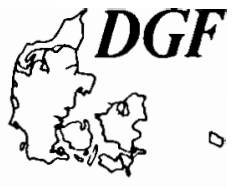

Bennike, O., Funder, S. \& Hjort, C.: Notes on the Holocene marine fauna of eastern North Greenland. Bull. geol. Soc. Denmark, vol. 35, pp. 71-74, October, 29th, 1986.

https://doi.org/10.37570/bgsd-1986-35-08

\begin{abstract}
A list of invertebrates, notably molluscs, from the raised Holocene marine sedimets in eastern North Greenland is given. The faunas have low diversity, and contain an element of Arctic sublittoral and bathyal species indicative of cold surface water.
\end{abstract}

O. Bennike \& S. Funder, Geological Museum, Øster Voldgade 5-7, DK-1350 Copenhagen K. C. Hjort, Department of Quaternary Geology, Sölvegatan 13, S-223 62 Lund. January 29th, 1986.

During the GGU expeditions to the Peary Land region, North Greenland, in 1979 and 1980, we collected molluscs and other invertebrates in the raised marine deposits of the region (fig. 1). The material was collected partly for ${ }^{14} \mathrm{C}$-dating, partly for investigations on the fauna.

Previous faunistic work is confined to a list of moluscs collected by members of the Danish Peary Land Expeditions (Laursen 1954), and some scanty information in Funder (1982), Funder \& Hjort (1980), Jensen (1917) and Weidick (1977, 1978).

As in other arctic areas Hiatella arctica and Mya truncata are by far the most common species (table 1). They are usually found together, and they both appear to be primarily members of the imfauna, because their shells often occur paired and in life position in the sediments in which they lived. Mya truncata is represented by typical $M$. truncata and by $M$. truncata var. uddevalensis Forbes, whereas $M$. truncata var. ovata Jensen (=M. pseudoarenaria Schlesch) has not been observed. Astarte borealis is very common, sometimes dominant, in faunas at low elevations, but also occurs at fairly high elevations. Hiatella arctica shells with borings in the posterior part were encountered in a few samples. The borings have been identified as ichnogenera Caulostrepsis (Bromley \& D'Alessandro 1983), and were probably made by the polychaete Polydora. Subfossil

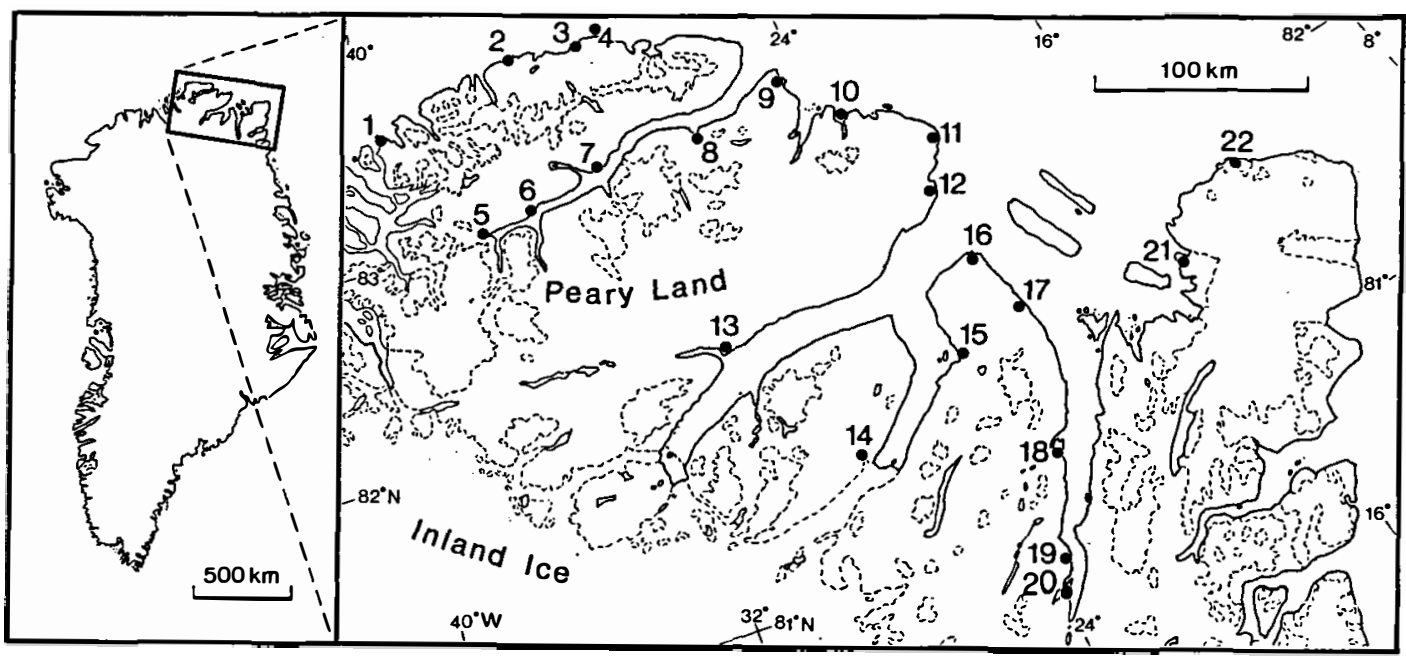

Fig. 1. Sites for collection of faunas. Locality numbers refer to the fauna list (table 1). 
Age, year BP (Funder 1982)

Altitude, m above sea level

GGU sample No

Locality No

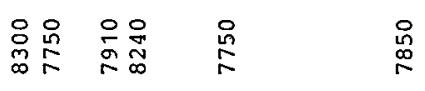

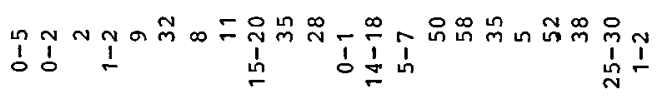

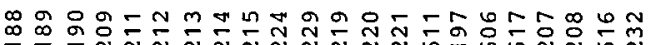

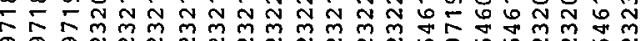

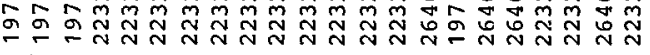

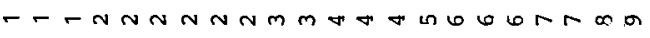

Foraminifera

Cyclogyra foliaceae (Philippi) - - - - - Polychaeta

Caulostrepsis ichnosp. - - - - - - - - -

Serpulidae - - - - - - - - - - - -

Gastropoda

Margarites groenlandicus (Gmelin) - - - - -

Trichotropis borealis (Broderip \& Sowerby) - Natica clausa (Broderip \& Sowerby) - - - - Colus togatus (Mörch) - - - - - - - - - Buccinum cf. hydrophanum - - - - - - - Oenopota sp. - - - - - - - - - - - - Cylicna sp. - - - - - - - - - - - Bivalvia

Nuculana pernula (Leche) - - - - - - - Portlandia aretica (Gray) - - - - - - - Portzandia frigida (Torell) - - - - - - - Area glacialis Gray - - - - - - - - - Modiolaria nigra (Gray) - - - - - - - - Propeamussium groen Zandicum (Sowerby) - - - Lima hyperborea (Jensen) - - - - - - - Astarte borealis (Chemnitz) - - - - - - - Astarte elliptica (Brown) - - - - - - - Astarte crenata.ssp. inflata Hägg - - - - Thyaşira gouldi (Philippi) - - - - - - Hiatelia arotica (Linne) - - - - - - - Mya truncata Linne - - - - - - - - - Pandora glacialis Leach - - - - - - - Thracia devexa G. O. Sars - - - - - - - Bryozoa

Porella concinna var. belli (Dawson) - - - Palmicellaria skenei Ellis \& Solander - - - ?Cyclostomata - - - - - - - - - - - - Echinoidea

Strongylocentrotus pallidus G. O. Sars - - Strongylocentrotus droebachensis o. F. Müller -

Table 1. The invertebrate fauna in some Holocene, marine deposits of eastern North Greenland. 


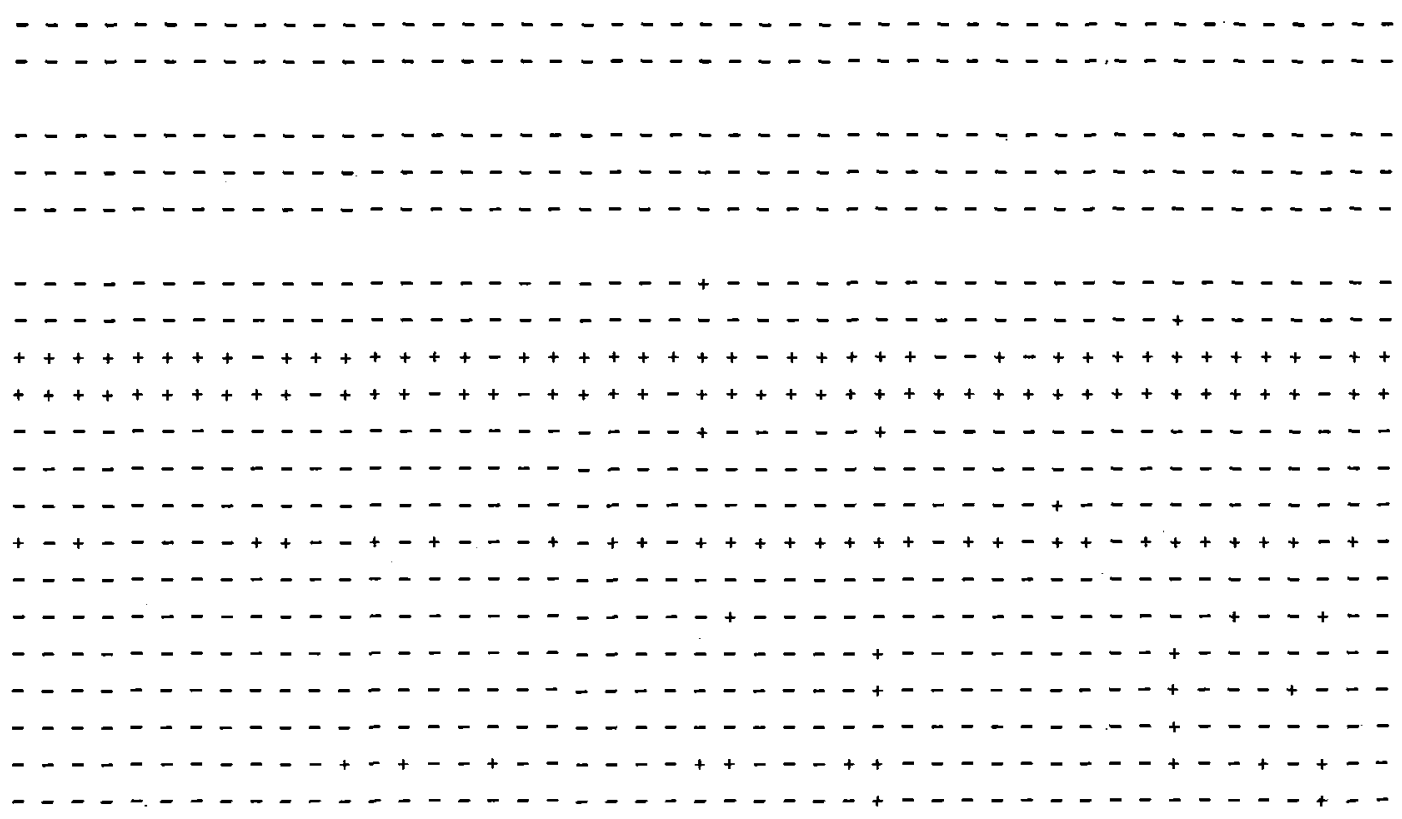

- - - - - - - - - - - - - - - - - - - - - - - - - - - - - - + - - - - - - - - - - - - - - - - - - - - - - + - - - + - - - - - - - - - - - - - - - - - - - - - - - - - - - - - - - - + - - - - - - - - - - - - - - - - - - - - - - - - - - - - - - - - - - - - - - - - - - - - - - - - - - - - - - - - - - - - - - - - - - - - - - - - - - - - - - - - - - - - - - - - - - - -

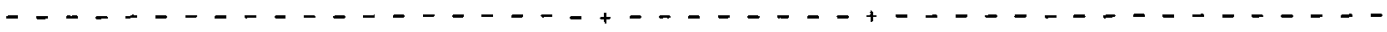
- - - - - - - - - - - - - - - - + - - - - - - - - - - - - - - + - - - - - - - - - - - - - - - - - - - - - - - - - - - - - - - - -

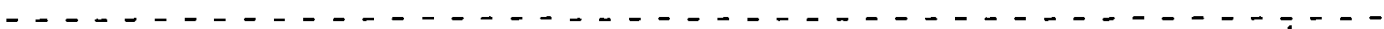

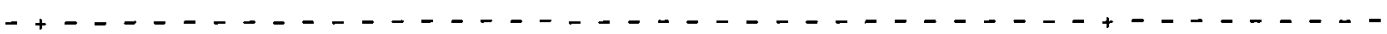

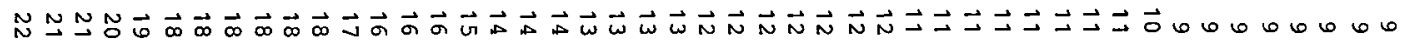

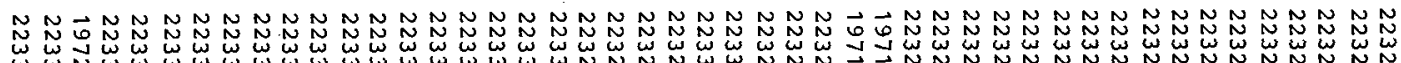

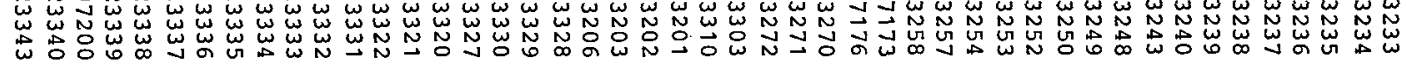

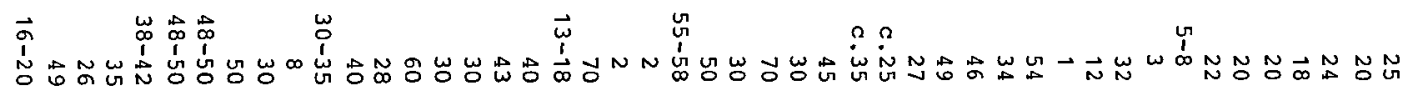

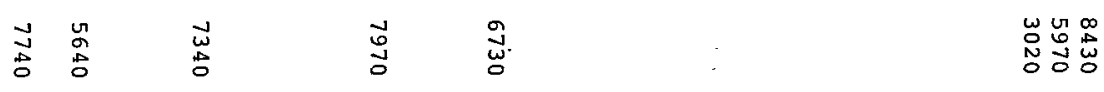


shells with similar borings have been observed in material from central North Greenland and from the Danmarkshavn area, and in a Littorina shell from the Scoresby Sund area (Funder 1978). The only Polydora species which has been taken alive in Greenland is $P$. coeca (Wesenberg-Lund 1950, 1953). This species is mainly distributed in boreal and lusitanian waters and is considered rare in the Arctic. Our findings indicate, that the species is present even in the high-arctic.

Sample 197189 from locality No 1 (Kap Kane) comes from a tiny island, consisting of gravel and situated some hundred metres from the mainland coast. The island resembles Oodaq $\emptyset$ off northern Peary Land, as does its fauna (Funder \& Hjort 1980). The fauna is considered to be subrecent, because it includes a number of well preserved thin shells. The shells have probably been transported out of the water by sea ice push.

The area studied lies far to the north of the zoogeographical boundary between the subarctic and the arctic, and hence is not sensitive to shifts in this boundary. Although the recent fauna of the region has been little studied due to sampling difficulties, all the reported species presumably occur in the region today.

The fauna is less diverse than Holocene faunas from East and West Greenland. It includes a number of taxa which have only rarely been recorded as subfossils, such as Portlandia frigida, Arca glacialis, Lima hyperborea, Astarte crenata inflata and Pandora glacialis. These species are all members of the Arctic sublittoral and bathyal fauna communities, and their occurence along the Arctic Ocean coasts may indicate very low temperatures in the surface water. On the other hand, species like Serripes groenlandicus and Macoma calcarea, which are rather common in subfossil faunas in East Greenland (Funder 1978), have not been recorded in Holocene deposits from eastern North Greenland.
Acknowledgements. This paper is published with the permission of the Director of the Geological Survey of Greenland. C. Rasmussen prepared the figure, $K$. Bille Hansen identified the bryozoans, R. G. Bromley and J. Kirkegaard identified the polychaete borings and $\mathbf{R}$. Feyling-Hanssen identified the foraminifera. R. J. Braithwaite checked the English language.

\section{Dansk sammendrag}

Holocæne, marine aflejringer er vidt udbredte i det østlige Nordgrønland. Aflejringernes makroskopiske invertebratfauna domineres of muslingerne Hiatella arctica, Mya truncata og Astarte borealis. Udover muslinger findes der arter af snegle, børsteorme, mosdyr, søpindsvin og foraminiferer. Faunaerne, der præges af lav diversitet, indeholder en række arter der indicerer, at overfladevandet ved det Arktiske Ocean er meget koldt.

\section{References}

Bromley, R. G. \& D'Alessandro, A. 1983: Bioerosion in the Pleistocene of southern Italy: ichnogenera Caulostrepsis and Maeandropolydora. Riv. It. Paleont. Strat. 89, 283309.

Funder, S. 1978: Holocene stratigraphy and vegtation history in the Scoresby Sund area, East Greenland. Bull. Grønlands geol. Unders. 129, $66 \mathrm{pp}$.

Funder, S. 1982: ${ }^{14} \mathrm{C}$-dating of samples collected during the 1979 expedition to North Greenland. Rapp. Grønlands geol. Unders. 110, 9-14.

Funder, S. \& Hjort, C. 1980: A reconnaissance of the Quaternary geology of eastern North Greenland. Rapp. Grønlands geol. Unders. 99, 99-105.

Jensen, A. S. 1917: Quaternary fossils collected by the Danmark Expedition. Meddr Grønland 43, 619-632.

Laursen, D. 1954: Emerged Pleistocene marine deposits of Peary Land (North Greenland). Meddr Grønland 127 (5), $26 \mathrm{pp}$.

Weidick, A. 1977: $\mathrm{C}^{14}$ dating of survey material carried out in 1976. Rapp. Grønlands geol. Unders. 85. 21-24.

Weidick, A. 1978: $\mathrm{C}^{14}$ dating of survey material carried out in 1977. Rapp. Grønlands geol. Unders. 90, 119-124.

Wesenberg-Lund, E. 1950: The Polychaeta of West Greenland with special reference to the fauna of Nordre Strømfjord, Kvane- and Bredefjord. Meddr Grønland 151 (2). 171 pp.

Wsenberg-Lund, E. 1953: The zoology of East Greenland. Polychaeta. Meddr Grønland 122 (3), 169 pp. 